\title{
Evaluation of basil extract (Ocimum basilicum L.) on oxidative, anti- genotoxic and anti-inflammatory effects in human leukocytes cell cultures exposed to challenging agents
}

\author{
Camila Martins Güez ${ }^{1}$, Raul Oliveira de Souza², Paula Fischer², Maria Fernanda de Moura Leão², \\ Jonathaline Apollo Duarte ${ }^{1}$, Aline Augusti Boligon², Margareth Linde Athayde ${ }^{2}$, Luísa Zuravski ${ }^{1}$, \\ Luís Flávio Souza de Oliveira1, Michel Mansur Machado1,*
}

${ }^{1}$ Curso de Pós-Graduação em Ciências Farmacêuticas, Universidade Federal do Pampa, Uruguaiana, Rio Grande do Sul, Brasil, ${ }^{2}$ Departamento de Farmácia Industrial, Curso de Farmácia, Universidade Federal de Santa Maria, Santa Maria, Rio Grande do Sul, Brasil

\begin{abstract}
Ocimum is one of the most important genera of the Lamiaceae family. Several studies about basil and its popular use reveal many characteristics of the herb, including its use as antioxidant, anti-aging, antiinflammatory, anti-carcinogenic, anti-microbial, and cardiovascular agents, among others. In this paper, we evaluated genotoxic, oxidative, and anti-inflammatory parameters from the extract of Ocimum basilicum in different concentrations, using human leukocytes cultures exposed to challenging agents. Our results confirm that the $O$. basilicum extract acts as an antioxidant and effectively reverts or subjugates the effects of high oxidizing agents such as hydrogen peroxide. These actions are attributed to its composition, which is rich in polyphenols and flavonoids as well as compounds such as rosmarinic acid, all of which have well-known antioxidant activity. We also show that our basil extract presents anti-inflammatory properties, the mechanism of which is a composed interaction between the inhibition of pro-inflammatory mediator and the stimulation of anti-inflammatory cytokines. Although pharmacodynamics studies are necessary to evaluate the activities in vivo, our results demonstrated that basil could act as an antioxidant and anti-inflammatory and a possible alternative for medicinal treatment.
\end{abstract}

Uniterms: Ocimum basilicum/evaluation. Ocimum basilicum/genotoxic effects. Ocimum basilicum/ anti-inflammatory properties. Medicinal plants/study.

\section{INTRODUCTION}

The free radicals are oxidizing agents, having one or more unpaired electrons in their outer orbit, making them highly reactive species that act as electrophiles (Wills, Thomas, Gillham, 1989). The reactions of free radicals with the organism result in cell and tissue damage that contributes to the development of pathologies. The free radicals act on cellular components by oxidizing lipids, proteins, nucleic acids, and carbohydrates (Choi et al., 2002).

The genus Ocimum L. includes approximately 150 species, possessing a great variation in plant morphology and biology, essential oil content, and

\footnotetext{
*Correspondence: M.M. Machado. Universidade Federal do Pampa. Campus Uruguaiana. BR 472, Km 585. Caixa Postal 118, 97500-970 - Uruguaiana - RS, Brasil. E-mail: michelmachado@unipampa.edu.br
}

chemical composition (Danesi et al., 2008). Ocimum basilicum, popular known as Basil or Sweet Basil, is a common herb that belongs to Lamiaceae family. Studies have shown many pharmacological effects in several diseases, with potent antioxidant, anti-aging, anticancer, antiviral, and antimicrobial properties (Sakr, Al-Amoudi, 2012). Studies have reported that rosmarinic acid (RA) is the most biologically active compound present in Basil related to this activities (Javanmardi et al., 2002; Lee, Scagel, 2009; Shiga et al., 2009).

Traditionally, basil has been used as a medicinal and aromatic herb, to add aroma and flavor to food (Vieira, Simon, 2000) basil contains several secondary metabolites like polyphenols, flavonoids, and terpenes, with recognized potential biologic effects that have been identified in this species (Lee, Scagel, 2009). Researchers have also tried to establish a standard of composition for 
basil, both in the extract and in oil, but the existence of more than 25 different types of $\mathrm{O}$. basilicum, with many constitutional differences (Lee et al., 2005; Liber et al., 2011) makes the task impossible.

The economic importance and global dissemination of basil, with its many uses in cooking and folk medicine, make it important to investigate its pharmacological and toxicological effects in order to ensure its efficacy and safety. Toxicity studies for these species are rare and do not focus on genetic aspects of toxicity to human cells. The main purpose of the present study was to evaluate the oxidative, genotoxic, and anti-inflammatory parameters that may be present in the extract from Basil leaves using human leukocyte cell cultures.

\section{MATERIAL AND METHODS}

\section{Chemical, apparatus and general procedures}

All chemicals were of analytical grade. Methanol, acetic acid, gallic acid, chlorogenic acid, and caffeic acid purchased from Merck (Darmstadt, Germany). Quercetin, rutin, rosmarinic acid, and kaempferol were acquired from Sigma Chemical Co. (St. Louis, MO, USA). High performance liquid chromatography (HPLC-DAD) was performed with a Shimadzu Prominence Auto Sampler (SIL-20A) HPLC system (Shimadzu, Kyoto, Japan) equipped with Shimadzu LC-20AT reciprocating pumps connected to a DGU 20A5 degasser with a CBM 20A integrator, SPD-M20A diode array detector, and LC solution 1.22 SP1 software.

\section{Plant material}

The commercial dry leaves of $O$. basilicum L., variety Genovese (Chá \& Cia Produtos Naturais ${ }^{\circledR}$, Jacareí, SP), were purchased from a local market in Uruguaiana, RS, Brazil (latitude $29^{\circ} 45^{\prime} 17^{\prime \prime}$; longitude $57^{\circ} 05^{\prime} 18^{\prime \prime}$ ). The leaves were triturated and macerated at room temperature in hydroalcoholic solution $\left(30 \mathrm{H}_{2} \mathrm{O}: 70\right.$ ethanol v/v) at concentration of $20 \mathrm{~g}$ per $100 \mathrm{~mL}$ of solvent for one week under daily shaking. The maceration process was repeated for two more weeks to exhaustion of the vegetable material. At the end of three weeks, the filtrates were pooled and evaporated under reduced pressure in a rotary evaporator in order to remove ethanol and water. The dry extract of $O$. basilicum (ObE) was used in the following tests.

\section{Determination of total polyphenolic contents}

The total polyphenol concentration in the crude extract was measured spectrophotometrically using a modified Folin-Ciocalteau method (Chandra, Gonzalez De Mejia, 2004). Briefly, we added $0.5 \mathrm{~mL}$ of $2 \mathrm{~N}$ FolinCiocalteau reagent to $1 \mathrm{~mL}$ of each sample $(0.15 \mathrm{mg} / \mathrm{mL})$ and allowed this mixture to stand for $5 \mathrm{~min}$ before adding $2 \mathrm{~mL}$ of $20 \% \mathrm{Na}_{2} \mathrm{CO}_{3}$. Next we allowed the solution to stand for $10 \mathrm{~min}$ before reading it in a Shimadzu-UV-1201 spectrophotometer (Shimadzu, Kyoto, Japan) at $730 \mathrm{~nm}$. We estimated the phenolic compounds in the crude extract in triplicate. Because of the chemical heterogeneity of plant products and the specificity of phenolic reagents, it is very difficult to choose suitable standards for identifying all phenols in a plant extract. Aqueous solutions of gallic acid in the range of $0.001-0.2 \mathrm{mg} / \mathrm{mL}$ as references was used. Thus, it is only possible to get relative equivalents with the standard used. The total polyphenol content was expressed as milligram equivalents of gallic acid per milliliter of the extract.

\section{Determination of total flavonoids}

Methanolic solutions of quercetin in the range of $4.0-12.0 \mu \mathrm{g} / \mathrm{mL}$ as references was used. To $2 \mathrm{~mL}$ of each reference solution, we added $20 \mathrm{~mL}$ of methanol and $1 \mathrm{~mL}$ of $5 \%$ methanolic solution of $\mathrm{AlCl}_{3}(\mathrm{w} / \mathrm{v})$ and produced a total volume of $50 \mathrm{~mL}$ with methanol at $20^{\circ} \mathrm{C}$. After 30 min, we measured the absorbance in a Shimadzu-UV-1201 spectrophotometer at $425 \mathrm{~nm}$. We used the same procedure to analyze the crude extract. The blank was $5 \% \mathrm{AlCl}_{3}(\mathrm{w} / \mathrm{v})$ (Woisky, Salatino, 1998). We estimated the flavonoids in crude extract in triplicate. The contents were expressed as milligram equivalents of quercetin/ $\mathrm{mL}$ of the extracts.

\section{High performance liquid chromatography}

Apparatus: The extracts were examined with high performance liquid chromatography (HPLC) using an HPLC system (Shimadzu, Kyoto, Japan), Prominence auto sampler (SIL-20A), which was equipped with Shimadzu LC-20 AT reciprocating pumps connected to a degasser DGU 20A5 with an integrator CBM 20A, a UV-VIS detector DAD (diode) SPD-M20A, and the Software LC solution 1.22 SP1.

\section{Analysis of phenolic compounds}

Reverse phase chromatographic analyses were performed under gradient conditions using a $\mathrm{C} 18$ column $(4.6 \mathrm{~mm} \times 150 \mathrm{~mm})$ packed with $5-\mu \mathrm{m}$ diameter particles. The mobile phase was water containing $2 \%$ acetic acid (A) and methanol (B). The composition gradient was 5\% of $\mathrm{B}$ to $2 \mathrm{~min}$, when it was changed to obtain $25 \%, 40 \%$, 
$50 \%, 60 \%, 70 \%$, and $100 \% \mathrm{~B}$ at $10,20,30,40,50$, and $80 \mathrm{~min}$, respectively, following the method described by Laghari et al. (2011) with slight modifications. The extracts were analyzed at a concentration of $0.150 \mathrm{mg} /$ $\mathrm{mL}$. We investigated the presence of the following six antioxidants: gallic acid, chlorogenic acid, caffeic acid, quercetin, rutin, and kaempferol. These compounds were identified by comparing their retention times and UV absorption spectra with those of the commercial standards. The flow rate was $0.7 \mathrm{~mL} / \mathrm{min}$ and the injection volume was $40 \mu \mathrm{L}$. The wavelengths were $254 \mathrm{~nm}$ for gallic acid; $327 \mathrm{~nm}$ for caffeic and chlorogenic acids; and $365 \mathrm{~nm}$ for quercetin, rutin, and kaempferol. The samples and mobile phase were filtered through a $0.45-\mu \mathrm{m}$ membrane filter (Millipore) and then degassed in an ultrasonic bath before use. Stock solutions of reference standards were prepared in the HPLC mobile phase for quercetin, rutin, and kaempferol at $0.020-0.200 \mathrm{mg} / \mathrm{mL}$ and for gallic, caffeic, and chlorogenic acids at $0.050-0.250 \mathrm{mg} / \mathrm{mL}$. A chromatography peak was confirmed by DAD spectra $(200-500 \mathrm{~nm})$ and by comparing its retention time with that of a reference standard.

\section{Cytotoxicity curve in leukocytes}

Initially, the dose-effect cytotoxicity curve was determined in leukocytes using ObE dissolved in PBS Buffer $\mathrm{pH} 7.2$ at doses ranging from $0.0001 \mathrm{mg} / \mathrm{mL}$ to $100 \mathrm{mg} / \mathrm{mL}$, to determine the lethal dose $50 \%$ (LD50). Human leukocytes cultures were prepared using $0.5 \mathrm{~mL}$ of venous blood collected by venipuncture from a male volunteer (survey approved by the Ethics Committee of the Federal University of Santa Maria, approval letter number 23,081). They were centrifuged to separate leukocytes and immediately transferred to RPMI 1640 medium supplemented with $10 \%$ fetal bovine serum, $1 \%$ streptomycin/penicillin, and phytohemagglutinin according to a previous study described by Montagner $\mathrm{et} \mathrm{al}$. (2010). Cells were kept at $37^{\circ} \mathrm{C}$ for $72 \mathrm{~h}$. The analyzed parameter was cell proliferation according to Burow et al. (1998).

\section{Leukocytes culture sample preparations}

To assess the anti-oxidative status and antigenotoxic profiles, the leukocyte cultures were divided in six groups. The groups were a negative control (phosphate buffer $\mathrm{pH}$ 7.2); a positive control (hydrogen peroxide $100 \mu \mathrm{M}$ ); a group with rosmarinic acid at the concentration previously found in the plant by the phytochemical analysis; and three groups with different extract concentrations obtained from toxicity studies; that is, the $\mathrm{LD}_{50}, \mathrm{LD}_{50 / 10}$, and $\mathrm{LD}_{50 / 100}$. Groups with rosmarinic acid and extracts have also received $100 \mu \mathrm{M}$ $\mathrm{H}_{2} \mathrm{O}_{2}$ to induce oxidation. To assess the inflammatory parameters the same groups division described above were used, with exception of positive control that has incorporated ibuprofen $100 \mu \mathrm{M}$. Additionally, all groups except the negative control received dextran $1 \%$ to induce the inflammatory process. The concentrations were selected to establish effective doses and exhibit low toxicity to leukocytes. All tests were performed in triplicate.

\section{Evaluation of antioxidants parameters of ObE in human leukocytes cultures}

To analyze the oxidative parameters, we used classical techniques as lipid peroxidation, protein carbonylation, ascorbic acid content, and superoxide dismutase and catalase activities. The assays were conducted in triplicates.

\section{Lipid peroxidation}

The extent of lipid peroxidation was estimated as the concentration of thiobarbituric acid reactive products (malondialdehyde) according to Ohkawa, Ohishi, Yagi (1979). The method spectrophotometrically measures the color produced by the reaction of TBA with malondialdehyde (MDA) at $532 \mathrm{~nm}$.

\section{Protein carbonylation}

The protocol was performed according to Morabito et al. (2004). In this technique, carbonyl (CO) groups (aldehydes and ketones) are produced on protein side chains when they are oxidized, reacting with 2,4-dinitrophenylhydrazine, forming a color complex.

\section{Ascorbic acid content}

According to the method of Jacques-Silva et al. (2001) the curve of ascorbic acid was taken as a reference and the reference samples were mixed with trichloroacetic acid $13.3 \%$ and 2,4-dinitrophenylhydrazine. After incubation period, the samples were measured at $520 \mathrm{~nm}$ in spectrophotometer. The extracts were measured using the same procedure.

\section{Catalase activity}

Catalase activity was determined from the rate of decomposition of $\mathrm{H}_{2} \mathrm{O}_{2}$ (Aebi, 1984). One unit of catalase activity was defined as the required activity to degrade one mol of hydrogen peroxide in $60 \mathrm{~s}$. 
Superoxide dismutase activity

Superoxide dismutase (SOD) (E.C.1.15.1.1) activity was measured spectrophotometrically according to Boveris, Cadenas (1997). The technique is based on the inhibition of the reaction of superoxide anion with epinephrine. The oxidation reaction of epinephrine produces adrenocromo, which can be detected spectrophotometrically $(480 \mathrm{~nm})$. The enzyme activity was determined by measuring the rate of formation of adrenocromo. The reaction medium contains glycine- $\mathrm{NaOH}$ and epinephrine. A unit of enzyme activity is defined as the amount of enzymes required to inhibit the rate of epinephrine autoxidation by $50 \%$.

\section{Evaluation of anti-genotoxic parameters of $\mathrm{ObE}$ in human leukocytes cultures}

The techniques used to evaluate the anti-genotoxic parameters were cell proliferation and unviability, DNA damage, chromosomal instability, and micronuclei frequency.

\section{Cellular proliferation and viability}

Viability is assessed by the loss of membrane integrity, using trypan blue (Burow et al., 1998). In this technique, the same samples and respective concentrations are combined with Turk's solution (acetic acid 3\% plus gentian violet $1 \%$ in water), and after three min, the sample is placed in a Neubauer chamber. The differentiation of living and dead cells is observed by the blue coloration of dead cells. A total of 300 cells are counted and the amount of total leukocytes (proliferation) is achieved through counting in a Neubauer chamber.

\section{Alkaline comet DNA assay}

This test was assayed following procedures of Singh et al. (1988). After incubation, the samples (leukocytes) were mixed with low-melting point agarose and placed on a microscope slide pre-coated with normal melting point agarose. The slides were immersed in a lysis solution, and an electrophoresis was performed (20 min at $300 \mathrm{~mA}$ and $25 \mathrm{~V})$. In the end, the slides were neutralized and left to dry overnight at room temperature. The dry slides were re-hydrated and then fixed for $10 \mathrm{~min}$, and allowed to dry again. The last stage was the coloring and the use of stop solution. The slides were analyzed under blind conditions. DNA damage was given as DNA damage index (DI). The DNA damage was calculated from cells in different damage classes.

\section{Chromosomal instability}

Colcemid was added in each leukocyte culture and incubated at $37^{\circ} \mathrm{C}$ during $60 \mathrm{~min}$. After this, the cells were centrifuged at 1,800 rpm for $10 \mathrm{~min}$. The cell pellets were re-suspended in hypotonic solution and incubated at $37^{\circ} \mathrm{C}$ for $16 \mathrm{~min}$. After a new centrifugation, the cell pellets were re-suspended in acetic acid: methanol (3:1) and poured into a flask containing a fixative solution (acetic acid and methanol 3:1) followed by centrifugation. The slides were prepared by dropping 3 or 4 drops of cell suspension into a cold, wet slide, which then was air dried. The cells were analyzed with $10 \times$ magnification to verify the density and distribution of metaphase chromosomes (Yunis, 1976).

\section{Micronuclei frequency}

The cells were placed in a conic tube with saline and centrifuged in 1,000 rpm for $5 \mathrm{~min}$ (this procedure was repeated). One milliliter with the cell pellet was kept in the tubes mixed with the pipette and spread over the slide (two per sample) and left to dry in room temperature. Slides were stained by panoptic method and then analyzed under optical microscopy in immersion lens. For each slide, 1,000 cells were counted (Schmid, 1975).

\section{Evaluation of anti-inflammatory parameters of ObE in human leukocytes cultures}

For the determination of tumor necrosis factor $-\alpha$ (TNF- $\alpha$ ), interleukine-10 (IL-10), interleukine-6 (IL-6), inhibition of COX-2 activities, and nitric oxide production, measurements were made using ELISA kits according to the manufacturer's instructions. All tests were performed in triplicate. The results of these tests were expressed in percentage of production in relation to the negative control.

\section{Statistical analysis}

Data were expressed as mean \pm standard deviation (SD). Comparisons between groups were performed using one-way analysis of variance (ANOVA), followed by post hoc of Bonferroni for multiple comparison tests. Nonlinear regression analysis was used to determine $\mathrm{LD}_{50}$. Results were considered statistically significant when $\mathrm{p}<0.05$.

\section{RESULTS AND DISCUSSION}

Medicinal plants are rich sources of natural antioxidants and represent a promising perspective in the discovery of new drugs in the therapeutic arena. Most members of the Lamiaceae family have exhibited interesting biological effects due to their antioxidant compounds (Schofield, Mbugua, Pell, 2001). 
Phenolic compounds are broadly distributed in the plant kingdom and are the most abundant secondary metabolites found in plants (Komali et al., 1999). The key role of phenolic compounds as antibacterial is emphasized in several reports (Møller et al., 1999; Schofield, Mbugua, Pell, 2001). Flavonoids compounds occur naturally in plant foods and are a common component of our diet. Table I shows the data from analysis by HPLC-DAD method (Rice-Evans, Miller, Paganga, 1996) to determine the concentration of totals polyphenol and flavonoids and some compounds present in $O$. basilicum $\mathrm{L}$, all described in literature as biologically active drugs.

In Figure 1, we show the dose-effect curve. As shown below, when the dose of the extract is increased,

TABLE I - Concentrations of some biologically important groups and compounds presents in the samples used of $O$. basilicum $\mathrm{L}$

\begin{tabular}{lc}
\hline Group / Compound & $\begin{array}{c}\text { Concentration in } \boldsymbol{\mu g} / \mathbf{m L} \text { of } \\
\text { Extract }\end{array}$ \\
\hline Polyphenol compounds & $23780.00 \pm 145.30$ \\
Total flavonoids & $15982.00 \pm 341.61$ \\
Quercetin & $558.37 \pm 2.41$ \\
Rutin & $398.49 \pm 0.97$ \\
Gallic acid & $2330.52 \pm 81.19$ \\
Caffeic acid & $4780.00 \pm 14.52$ \\
Chlorogenic acid & $2875.00 \pm 103.56$ \\
Rosmarinic acid & $353.00 \pm 2.87$ \\
Kaempferol & $342.00 \pm 18.79$ \\
\hline
\end{tabular}

Data are expressed as means \pm S.D. Results were confirmed by an experiment that was repeated three times. the total number of leukocytes decreases, showing a dose-dependent effect. It is important to note that in LD50 concentration $(35.44 \mu \mathrm{g} / \mathrm{mL})$, the cellular unviability and DNA damage showed no significant changes (data not shown), which agrees with the results by Gomez-Flores et al. (2008). This result allowed us to establish the doses that were used in our protocols. Aiming to search for a dose with high affectivities and low toxicity, we determine the work doses for this protocol: $35.44 \mu \mathrm{g} / \mathrm{mL}$ (LD50), 3.544 $\mu \mathrm{g} / \mathrm{mL}$ (LD50/10), and 0.3544 $\mu \mathrm{g} / \mathrm{mL}$ (LD50/100).

The accumulations of free radicals in organs or tissues are strongly associated with oxidative damages in biomolecules and cell membranes. This can lead to many chronic diseases, such as inflammatory, cancer, diabetes, aging, cardiac dysfunction, and other degenerative diseases (Wang et al., 2004). Figure 2 demonstrates the results found for oxidative parameters.

The involvement of reactive oxygen species in interactions with polyunsaturated fatty acids in cell membranes generates lipid peroxidation. The result is the formation of highly reactive hydro or lipoperoxides that may trigger the oxidative cascade, resulting in damage to membrane integrity (Tsang, Chung, 2009). The results found in lipid peroxidation show that LD50 and LD50/10 obtained values are close to the control of rosmarinic acid, a well-known antioxidant agent. Moreover, the values of peroxidation in LD50 3,576 nMol of MDA/ $\mathrm{mL}$ in erythrocytes and LD50/10 4,226 nMol of MDA/ $\mathrm{mL}$ in erythrocytes, were $41.81 \%$ and $31.29 \%$ lower when compared to the positive control, respectively. The content of protein carbonyl is the most general indicator and the most commonly used marker of protein oxidation,

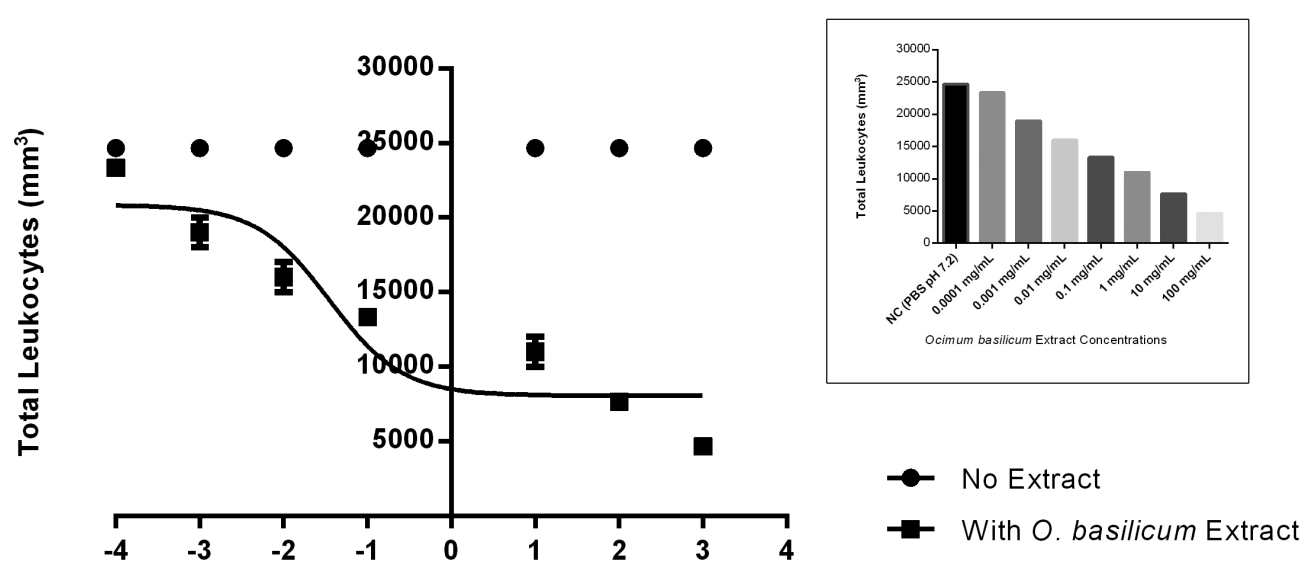

$\log [\mathrm{Ob}$ Extract]

FIGURE 1 - Dose-effect curve using the crude extract of Ocimum basilicum in different doses $(0.0001 \mathrm{mg} / \mathrm{mL}$ to $100 \mathrm{mg} / \mathrm{mL})$ to determine the lethal dose $50\left(\mathrm{LD}_{50}\right)$ in human leukocytes. The inset shows the total amount of leukocytes versus the tests concentrations of $O$. basilicum extract. 

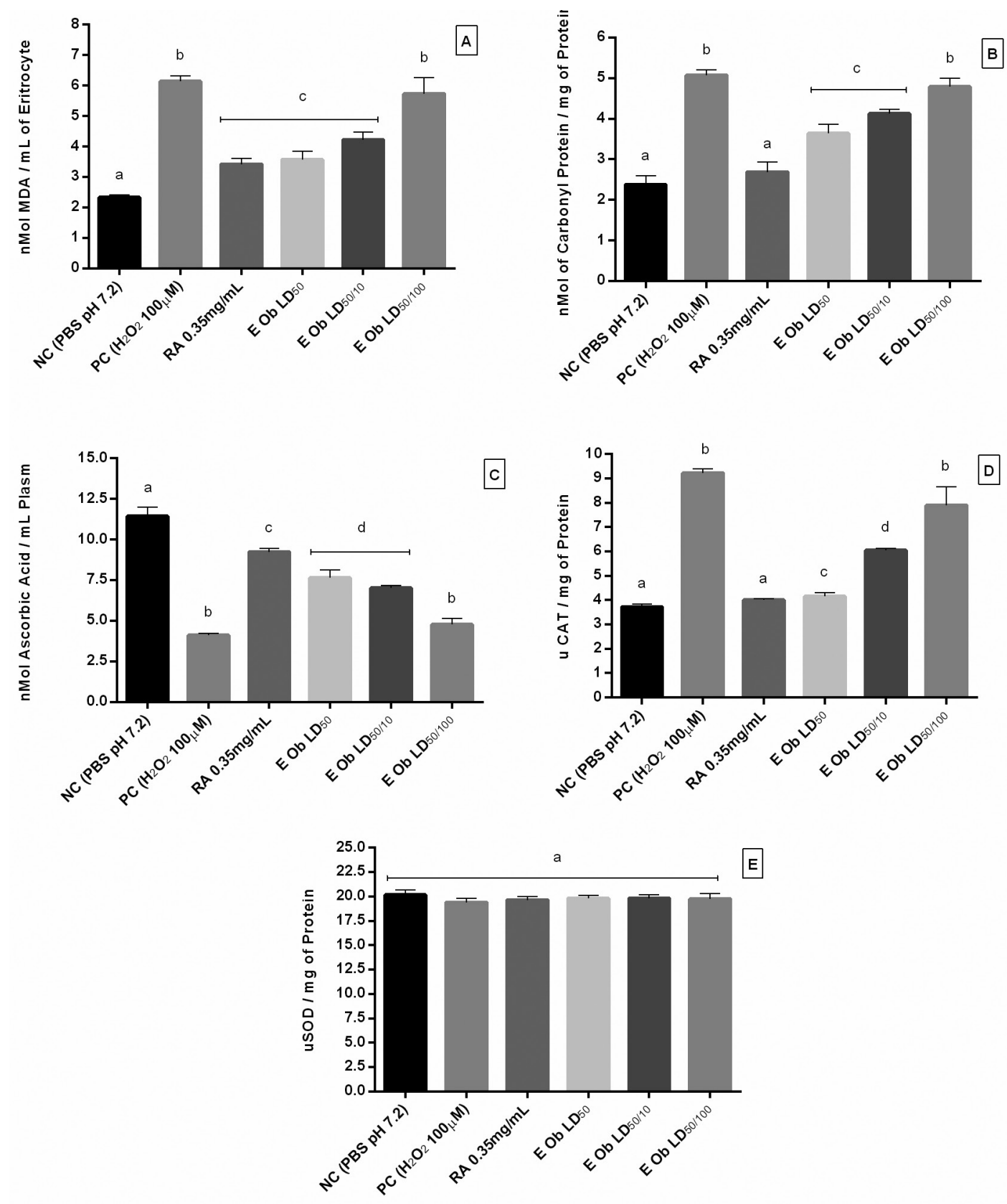

FIGURE 2 - Effects of $O$. basilicum extract in oxidative parameters of human leukocytes in culture subject to hydrogen peroxide. In A: lipid peroxidation; B; carbonyl contents; C: ascorbic acid; D: catalase activity; E: superoxide dismutase activity. NC: negative control; PC: positive control; RA: rosmarinic acid; $\mathrm{LD}_{50}$ : concentration equals to $\mathrm{LD}_{50}(35.44 \mu \mathrm{g} / \mathrm{mL}) ; \mathrm{LD}_{50 / 10}: 10$ times less the concentration of $\mathrm{LD}_{50}(3.544 \mu \mathrm{g} / \mathrm{mL}) ; \mathrm{LD}_{50 / 100}$ : One hundred times less the concentration of $\mathrm{LD}_{50}(0.3544 \mu \mathrm{g} / \mathrm{mL})$. Data are expressed as mean \pm S.D. Results were confirmed by an experiment that was repeated three times. Different letters represent statistically different results among columns $(\mathrm{p}<0.05)$.

and its accumulation has been observed in several human diseases. The values found in protein carbonyl show that LD50 was $28 \%$ and LD50/10 18.8\% lower when compared to the positive control, and approximate to negative control and rosmarinic acid control. Vitamin $\mathrm{C}$ or ascorbic acid has been implicated in different biological processes and plays an important role in oxidant defense. Ascorbic acid functions in several enzymatic steps, acting like a cofactor in the synthesis of collagen, monoamines, amino acids, peptide hormones, and carnitine. Samples with higher concentrations of extract showed higher concentrations of ascorbic acid. This fact is directly related to the concentrations of polyphenols and antioxidant action. The most concentrated samples, LD50 and DL50/10, have 
higher levels of polyphenols. Polyphenols are a first line of defense against oxidative action of hydrogen peroxide. When polyphenols decrease their concentrations, other non-enzymatic antioxidants come into play, thereby reducing the concentration of vitamin C (Kelm et al., 2000; Petersen, Simmonds, 2003).

Mammalian cells have elaborate antioxidant defense mechanisms to control damage effects of reactive oxygen species and the catalase enzyme is one of these, protecting cells against the toxic effects of hydrogen peroxide (Goyal, Basak, 2010). The results of catalase analysis show the ability of $O$. basilicum extract in neutralizing the effects of hydrogen peroxide. The results were dose-related and show a better effect at $\mathrm{LD}_{50}$ concentration. Superoxide has been implicated in reactions associated with aging and in pathophysiological processes due to its transformation into more reactive species such as hydroxyl radical, which initiates lipid peroxidation.

According to our results, the activity of SOD enzyme was not affected in the three concentrations of $O$. basilicum extract. All these results are related to the presence of antioxidant compounds present in the extract (Table I), as the groups of polyphenols and flavonoids. This information confirms the data from the literature that phenolic compounds, especially flavonoids act in the oxidative metabolism, not by changing the enzymatic defenses, but by directing neutralizing of reactive species in order to stabilize them (Liu et al., 2008).

We also evaluated the effects of hydrogen peroxide and the counter effects of $O$. basilicum extract on human leukocytes cells. The results of these markers are show in Figure 3.

In cellular proliferation (Figure $3 \mathrm{~A}$ ), cellular increase of the concentrations of $\mathrm{LD}_{50}$ and $\mathrm{LD}_{50 / 100}$ was similar to the rosmarinic acid control and different from the positive control, whereas the lowest concentration $\mathrm{LD}_{50 / 100}$ presented a decrease in cellular proliferation, which may be compared to the positive control. Figure 3B shows the percentage of unviable cells for both controls groups and for the three concentrations groups tested. The negative control presented only $0.667 \%$, whereas positive control was $14 \%$ of unviable cells. Rosmarinic acid was $1.33 \%$ and the other three concentrations of $O$. basilicum: $\mathrm{LD}_{50}: 1.667 \% ; \mathrm{LD}_{50 / 10}$ : $3.67 \% ; \mathrm{LD}_{50 / 100}: 10.67 \%$ of unviable cells. Shimizu et al. (2013) in a pancreatic cancer model, shows that Ocimum sanctum, belonging to the same plant family tested here, leaves inhibit the proliferation, migration, invasion, and induce apoptosis of cells in vitro. It is important to note that these results were obtained in cancer cells and it would be inaccurate to extrapolate this statement for normal leukocytes, having a functional metabolism.
According to Collins et al. (2008), the high viability of cells is required as a previous condition for the performance of the comet assay. Chromosomal instability results in numerical and structural chromosomal complexity and several studies associated these instabilities with poor prognosis in solid tumors (Birkbak et al., 2011).

The results demonstrate that all concentrations of extract of basil have presented percentages of chromosomal abnormalities (Figure 3C) similar to the negative control, and even the lowest concentration presented $33.334 \%$ less mitotic index when compared to positive control.

The comet assay is one of the most promising genotoxicity tests developed to measure and analyze DNA damage in single cells (Mukhopadhyay et al., 2004). The test was used as a parameter for assessing the DNA damage index (Figure 3D). As we can see at the lowest concentration, LD50/100, the cells presented the highest damage index compared with positive control, whereas the other two concentrations of extract, LD50 and LD50/10, showed damage indexes of $44.45 \%$ and $19.18 \%$ lower when compared with the positive control, respectively.

The micronuclei assay provides a convenient and reliable index of both chromosome breakage and chromosome loss. The micronuclei are expressed in dividing cells that either contain chromosome breaks lacking centromeres (acentric fragments) and/or whole chromosomes that are unable to migrate to the poles during mitosis (Fenech, 2000). The results show the micronucleus frequency $(\mathrm{MN})$ found at the control groups and three concentrations of plant extract under analysis (Figure $3 \mathrm{E})$. The frequency of MN was dose-dependent. The lowest concentration of the extract has shown the highest frequency of cells with this alteration.

Basil was frequently reported as a common antiinflammatory (Narayanaswamy, Duraisamy, Balakrishnan, 2011). Aiming to confirm this activity and evaluate the mechanism involved, we perform a series of tests in human leukocytes cell exposed to a pro-inflammatory agent. The results are presented in Figure 4.

Cytokines are subdivided in proinflammatory (initiate defense against pathogens) and anti-inflammatory (regulate the inflammatory process helping to balance the inflammatory response) acting with an important role in inflammatory response. The proinflammatory cytokines includes IL-1, IL-2, IL-6, IL-8, and TNF- $\alpha$, and the anti-inflammatory cytokines includes IL-1 antagonist receptor, IL-4, IL-10, and IL-13 (Goldstein, Leung, Silverstein, 2006). The results show that the production of the proinflammatory cytokines such as TNF- $\alpha$ and IL- 6 was not affected in the three different 

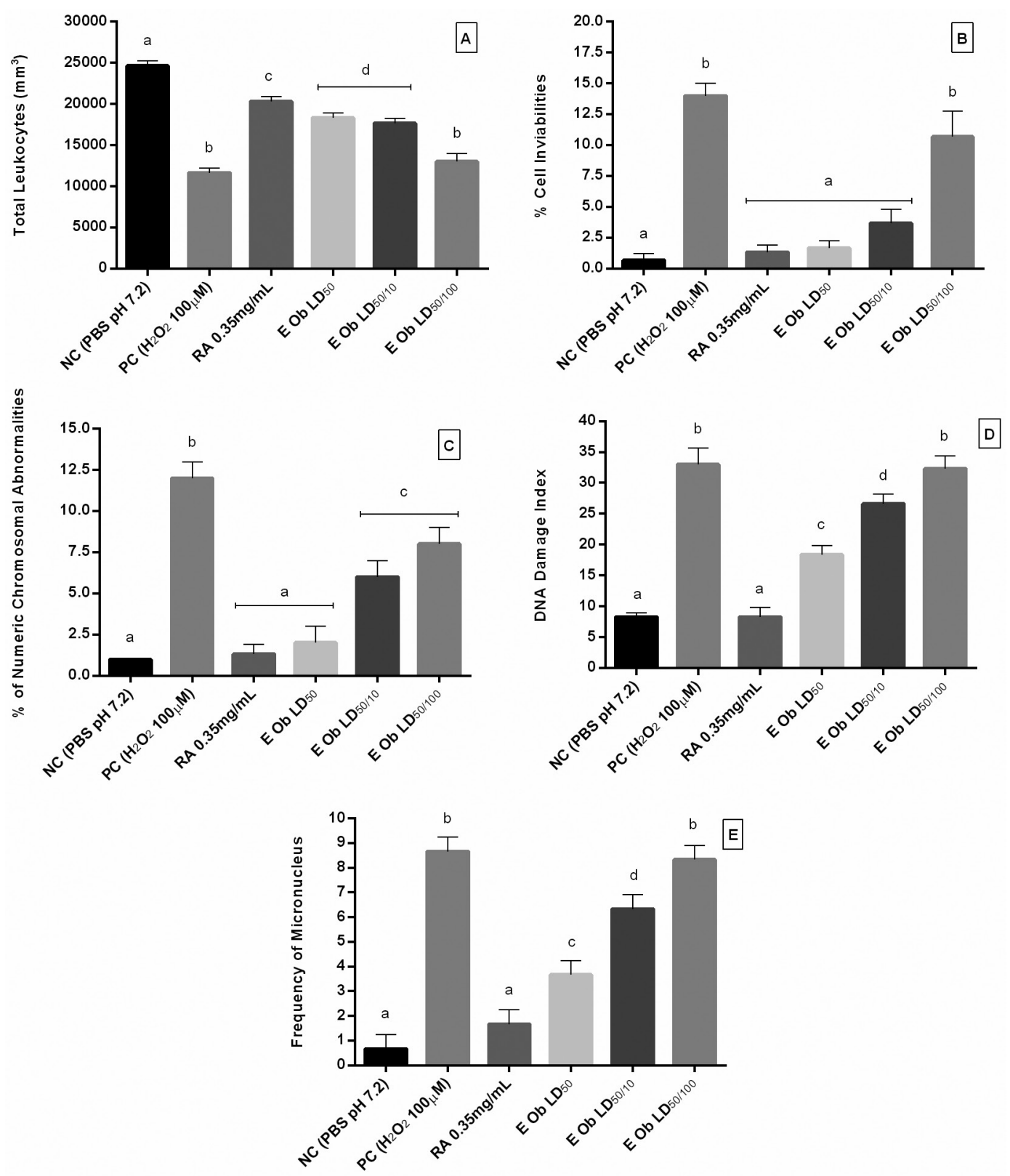

FIGURE 3 - Effects of $O$. basilicum extract in anti-genotoxic parameters of human leukocytes in culture subject to hydrogen peroxide. In A: cell proliferation; B; cell inviability; C: percentage of abnormal chromossomics; D: DNA damage index; E: frequency of micronuclei. NC: negative control; PC: positive control; RA: rosmarinic acid; LD50: concentration equals to LD50 (35.44 $\mu \mathrm{g} /$ $\mathrm{mL})$; LD50/10: 10 times less the concentration of LD50 (3.544 $\mu \mathrm{g} / \mathrm{mL})$; LD50/100: One hundred times less the concentration of LD50 $(0.3544 \mu \mathrm{g} / \mathrm{mL})$. Data are expressed as mean \pm S.D. Results were confirmed by an experiment that was repeated three times. Different letters represent statistically different results among columns $(\mathrm{p}<0.05)$.

doses of $O$. basilicum extract. However, the percentage of production of IL-10, the anti-inflammatory cytokine, shows an increase in the percentage of more than $60 \%$ at the highest dose of the extract when compared with the positive control (ibuprofen). The percentage of production of IL-10 also demonstrated to be dose-dependent, but in all concentrations, this production was higher than the negative and positive controls. The cyclooxygenases
(COX) have been identified in three different isoforms. COX-2 acts like the inducible isoform, which is regulated by growth factors and different cytokines (IL1 $\beta$, IL6, or TNF $\alpha$ ) (Sobolewski et al., 2010). The ability of the extract from $O$. basilicum to inhibit COX-2 was determined and the results show that the extract was not capable to reduce the activity of the cyclooxygenase like the positive control (ibuprofen) but his activity decrease when compared to 

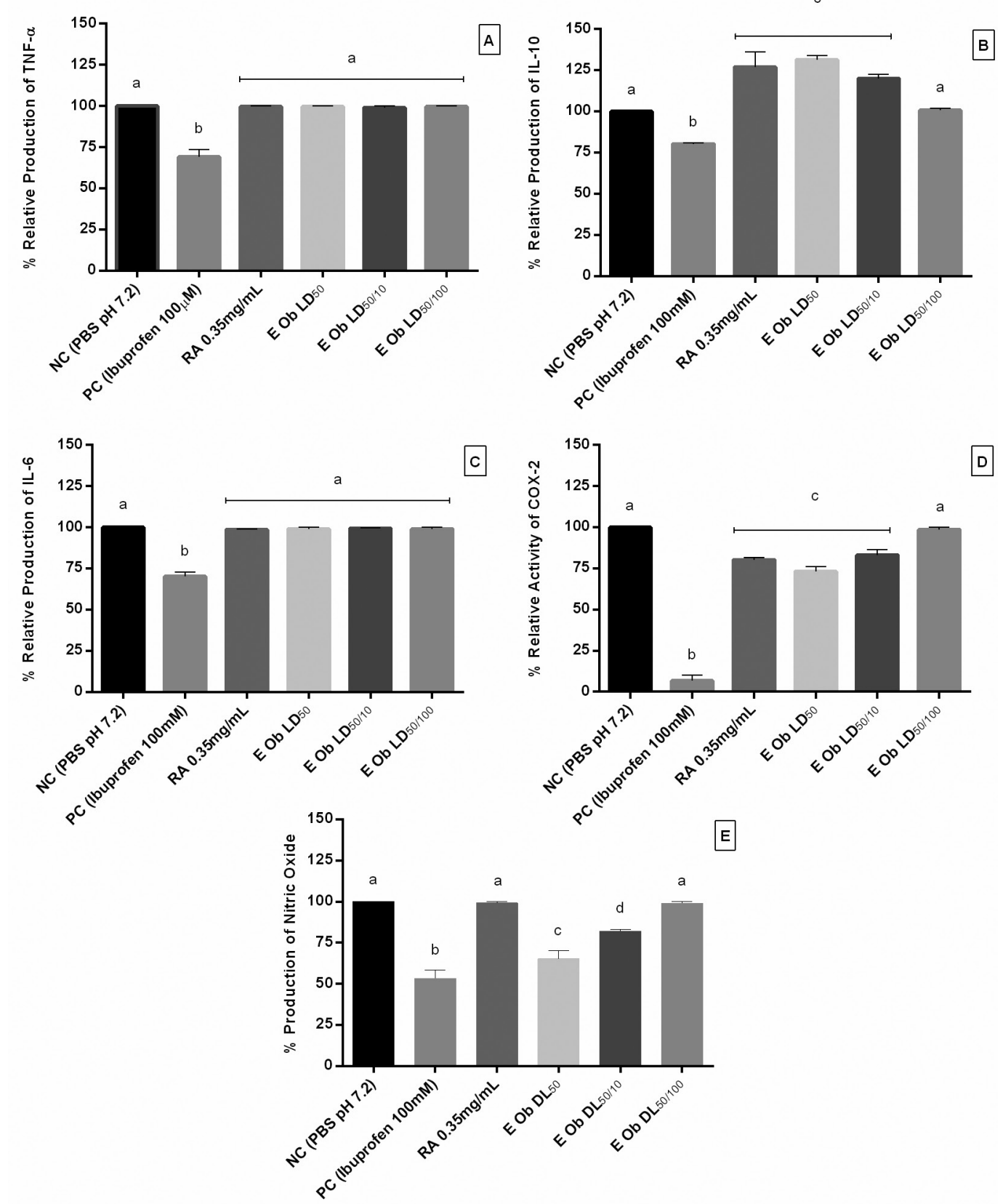

FIGURE 4 - Effects of $O$. basilicum extract in inflammatory parameters of human leukocytes in culture subject to dextran solution. All the results are presented as percentage in relation to the negative control. In A: tumoral necrose factor- $\alpha$ (TNF- $\alpha$ ); B; interleukine-10 (IL-10); C: interleukine-6 (IL-6); D: Ciclooxigenase type 2 activity (COX2 activity); E: nitric oxide (NO) production NC: negative control; PC: positive control; RA: rosmarinic acid; LD50: concentration equals to LD50 (35.44 $\mu \mathrm{g} / \mathrm{mL})$; LD50/10: 10 times less the concentration of LD50 $(3.544 \mu \mathrm{g} / \mathrm{mL})$; LD50/100: One hundred times less the concentration of LD50 $(0.3544 \mu \mathrm{g} / \mathrm{mL})$. Data are expressed as mean \pm S.D. Results were confirmed by an experiment that was repeated three times. Different letters represent statistically different results among columns $(\mathrm{p}<0.05)$.

the negative control (100\%) and was dose-dependent. The inhibition of COX-2 in LD50 and LD50/10 approximates to the inhibition caused by rosmarinic acid and several studies report many properties of rosmarinic acid including cyclooxygenase inhibition (Kelm et al., 2000; Petersen, Simmonds, 2003).
The percentage of nitric oxide generated was measured and cells pretreated with the three plant extracts showed a dose-dependent inhibition. The negative control was considered $100 \%$. The maximal NO inhibitory effect was exhibited by O. basilicum at dose of LD50. Comparing to the negative control, the 
percentage of reduction was higher than 30\% (34.67\%). In a similar study using three plants of Lamiaceae family, O. basilicum extract demonstrated the higher content of phenols and maximal levels of DNA protection and free radical scavenging against toxicity induced by cadmium chloride (Thirugnanasampandan, Jayakumar, 2011). The results suggested that the anti-inflammatory activities of these extracts could be explained, at least in part, by their antioxidant properties. Rosmarinic acid was one of the most abundant caffeic acid esters present in $\mathrm{O}$. basilicum (Jayasinghe et al., 2003). It has been related that this compound has antioxidant, anti-HIV, and antiinflammatory or cyclooxygenase and lipoxygenases inhibitory activities (Petersen, Simmonds, 2003).

\section{CONCLUSIONS}

It is possible to verify that $O$. basilicum extract acts as an antioxidant and effectively reverts or subjugates the effects of a high oxidizing agent such as hydrogen peroxide. These actions are explained by its composition, which is rich in polyphenols and flavonoids as well as compounds such as rosmarinic acid, which have a wellknown antioxidant activity.

Our study shows that Basil extract possesses antiinflammatory properties, and the mechanism involved is a composed interaction between the inhibition of pro-inflammatory mediator and the stimulation of antiinflammatory cytokines.

Although pharmacodynamic studies are necessary to evaluate the activities in vivo, our results demonstrated that Basil could act as antioxidant and anti-inflammatory, becoming a possible alternative for medicinal treatment.

\section{CONFLICT OF INTERESTS}

The authors declare no conflict of interests.

\section{ACKNOWLEDGMENTS}

The authors are thankful to the financial support of Fundação de Amparo a Pesquisa do Rio Grande do Sul (FAPERGS) and to Conselho Nacional de Desenvolvimento Científico e Tecnológico (CNPq) and to Wiener Lab Group by the donation of kits for evaluations of laboratory parameters.

\section{REFERENCES}

AEBI, H. Catalase in vitro. Methods Enzymol., v.105, p.121126, 1984.
BIRKBAK, N.J.; EKLUND, A.C.; LI, Q.; MCCLELLAND, S.E.; ENDESFELDER, D.; TAN, P.; TAN, I.B.; RICHARDSON, A.L.; SZALLASI, Z.; SWANTON, C. Paradoxical relationship between chromosomal instability and survival outcome in cancer. Cancer Res., v.71, n.10, p.3447-3452, 2011.

BOVERIS, A.; CADENAS, E. Cellular sources and steady-state levels of reactive oxygen species. Lung Biol. Health Dis., v.105, p.1-26, 1997.

BUROW, M.E.; WELDON, C.B.; TANG, Y.; NAVAR, G.L.; KRAJEWSKI, S.; REED, J.C.; HAMMOND, T.G.; CLEJAN, S.; BECKMAN, B.S. Differences in susceptibility to tumor necrosis factor $\alpha$-induced apoptosis among MCF-7 breast cancer cell variants. Cancer Res., v.58, n.21, p.4940-4946, 1998.

CHANDRA, S.; GONZALEZ DE MEJIA, E. Polyphenolic compounds, antioxidant capacity, and quinone reductase activity of an aqueous extract of Ardisia compressa in comparison to mate (Ilex paraguariensis) and green (Camellia sinensis) teas. J. Agric. Food Chem., v.52, n.11, p.3583-3589, 2004.

CHOI, C.W.; KIM, S.C.; HWANG, S.S.; CHOI, B.K.; AHN, H.J.; LEE, M.Y.; PARK, S.H.; KIM, S.K. Antioxidant activity and free radical scavenging capacity between Korean medicinal plants and flavonoids by assay-guided comparison. Plant Sci., v.163, n.6, p.1161-1168, 2002.

COLLINS, A.R.; OSCOZ, A.A.; BRUNBORG, G.; GAIVÃO, I.; GIOVANNELLI, L.; KRUSZEWSKI, M.; SMITH, C.C.; STETINA, R. The comet assay: topical issues. Mutagenesis, v.23, n.3, p.143-151, 2008.

DANESI, F.; ELEMENTI, S.; NERI, R.; MARANESI, M.; D'ANTUONO, L.F.; BORDONI, A. Effect of cultivar on the protection of cardiomyocytes from oxidative stress by essential oils and aqueous extracts of basil (Ocimum basilicum L.). J. Agric. Food Chem., v.56, n.21, p.99119917, 2008.

FENECH, M. The in vitro micronucleus technique. Mutat. Res., v.455, n.1/2, p.81-95, 2000.

GOLDSTEIN, S.L.; LEUNG, J.C.; SILVERSTEIN, D.M. Pro-and anti-inflammatory cytokines in chronic pediatric dialysis patients: effect of aspirin. Clin. J. Am. Soc. Nephrol., v.1, n.5, p.979-986, 2006. 
GOMEZ-FLORES, R.; VERÁSTEGUI-RODRÍGUEZ, L.; QUINTANILLA-LICEA, R.; TAMEZ-GUERRA, P.; TAMEZ-GUERRA, R.; RODRÍGUEZ-PADILLA, C. In vitro rat lymphocyte proliferation induced by Ocinum basilicum, Persea americana, Plantago virginica, and Rosa spp. extracts. J. Med. Plants Res., v.2, n.1, p.5-10, 2008.

GOYAL, M.M.; BASAK, A. Human catalase: looking for complete identity. Protein Cell, v.1, n.10, p.888-897, 2010.

JACQUES-SILVA, M.C.; NOGUEIRA, C.W.; BROCH, L.C.; FLORES, E.M.; ROCHA, J.B. Diphenyl diselenide and ascorbic acid changes deposition of selenium and ascorbic acid in liver and brain of mice. Pharmacol. Toxicol., v.88, n.3, p.119-125, 2001 .

JAVANMARDI, J.; KHALIGHI, A.; KASHI, A.; BAIS, H.P.; VIVANCO, J.M. Chemical characterization of basil (Ocimum basilicum L.) found in local accessions and used in traditional medicines in Iran. J. Agric. Food Chem., v.50, n.21, p.5878-5883, 2002.

JAYASINGHE, C.; GOTOH, N.; AOKI, T.; WADA, S. Phenolics composition and antioxidant activity of sweet basil (Ocimum basilicum L.). J. Agric. Food Chem., v.51, n.15, p.4442-4449, 2003.

KELM, M.; NAIR, M.G.; STRASBURG, G.M.; DEWITT, D.L. Antioxidant and cyclooxygenase inhibitory phenolic compounds from Ocimum sanctum Linn. Phytomedicine, v.7, n.1, p.7-13, 2000.

KOMALI, A.S.; ZHENG, Z.; SHETTY, K. A mathematical model for the growth kinetics and synthesis of phenolics in oregano (Origanum vulgare) shoot cultures inoculated with Pseudomonas species. Process Biochem., v.35, n.3, p.227-235, 1999.

LAGHARI, A.H.; MEMON, S.; NELOFAR, A.; KHAN, K.M.; YASMIN, A. Determination of free phenolic acids and antioxidant activity of methanolic extracts obtained from fruits and leaves of Chenopodium album. Food Chem., v.126, n.4, p.1850-1855, 2011.

LEE, J.; SCAGEL, C.F. Chicoric acid found in basil (Ocimum basilicum L.) leaves. Food Chem., v.115, n.2, p.650-656, 2009.
LEE, S.-J.; UMANO, K.; SHIBAMOTO, T.; LEE, K.-G. Identification of volatile components in basil (Ocimum basilicum L.) and thyme leaves (Thymus vulgaris L.) and their antioxidant properties. Food Chem., v.91, n.1, p.131$137,2005$.

LIBER, Z.; CAROVIĆ-STANKO, K.; POLITEO, O.; STRIKIĆ, F.; KOLAK, I.; MILOS, M.; SATOVIC, Z. Chemical characterization and genetic relationships among Ocimum basilicum L. cultivars. Chem. Biodivers., v.8, n.11, p.19781989, 2011

LIU, X.; CUI, C.; ZHAO, M.; WANG, J.; LUO, W.; YANG, B.; JIANG, Y. Identification of phenolics in the fruit of emblica (Phyllanthus emblica L.) and their antioxidant activities. Food Chem., v.109, n.4, p.909-915, 2008.

MØLlER, J.K.S.; MADSEN, H.L.; AALTONEN, T.; SKIBSTED, L.H Dittany (Origanum dictamnus) as a source of water-extractable antioxidants. Food Chem., v.64, n.2, p.215-219, 1999.

MONTAGNER, G.F.F.S.; SAGRILLO, M.; MACHADO, M.M.; ALMEIDA, R.C.; MOSTARDEIRO, C.P.; DUARTE, M.M.; CRUZ, I.B. Toxicological effects of ultraviolet radiation on lymphocyte cells with different manganese superoxide dismutase Ala16Val polymorphism genotypes. Toxicol. In Vitro, v.24, n.5, p.1410-1416, 2010.

MORABITO, F.; CRISTANI, M.; SAIJA, A.; STELITANO, C.; CALlEA, V.; TOMAINO, A.; MINCIULLO, P.L.; GANGEMI, S. Lipid peroxidation and protein oxidation in patients affected by Hodgkin's lymphoma. Mediators Inflamm., v.13, n.5/6, p.381-383, 2004.

MUKHOPADHYAY, I.; CHOWDHURI, D.K.; BAJPAYEE, M.; DHAWAN, A. Evaluation of in vivo genotoxicity of cypermethrin in Drosophila melanogaster using the alkaline Comet assay. Mutagenesis, v.19, n.2, p.85-90, 2004.

NARAYA N A S WA M Y, N .; DURA I S A M Y, A .; BALAKRISHNAN, K.P. Screening of some medicinal plants for their antityrosinase and antioxidant activities. Int. J. PharmTech. Res., v.3, p.1107-1112, 2011.

OHKAWA, H.; OHISHI, N.; YAGI, K. Assay for lipid peroxides in animal tissues by thiobarbituric acid reaction. Anal. Biochem., v.95, n.2, p.351-358, 1979.

PETERSEN, M.; SIMMONDS, M.S.J. Rosmarinic acid. Phytochemistry, v.62, n.2, p.121-125, 2003. 
RICE-EVANS, C.A.; MILLER, N.J.; PAGANGA, G. Structureantioxidant activity relationships of flavonoids and phenolic acids. Free Radicals Biol. Med., v.20, n.7, p.933-956, 1996.

SAKR, S.A.; AL-AMOUDI, W.M. Effect of leave extract of Ocimum basilicum on deltamethrin induced nephrotoxicity and oxidative stress in albino rats. J. Appl. Pharm. Sci., v.2, n.5, 2012.

SCHMID, W. The micronucleus test. Mutat. Res., v.31, n.1, p.9-15, 1975.

SCHOFIELD, P.; MBUGUA, D.; PELL, A. Analysis of condensed tannins: a review. Anim. Feed Sci. Technol., v.91, n.1, p.21-40, 2001.

SHIGA, T.; SHOJI, K.; SHIMADA, H.; HASHIDA, S.-N.; GOTO, F.; YOSHIHARA, T. Effect of light quality on rosmarinic acid content and antioxidant activity of sweet basil, Ocimum basilicum L. Plant Biotechnol., v.26, n.2, p.255-259, 2009. (Short Communication).

SHIMIZU, T.; TORRES, M.P.; CHAKRABORTY, S.; SOUCHEK, J.J.; RACHAGANI, S.; KAUR, S.; MACHA, M.; GANTI, A.K.; HAUKE, R.J.; BATRA, S.K. Holy Basil leaf extract decreases tumorigenicity and metastasis of aggressive human pancreatic cancer cells in vitro and in vivo: potential role in therapy. Cancer Lett., v.336, n.2, p.270-280, 2013.

SINGH, N.P.; MCCOY, M.T.; TICE, R.R.; SCHNEIDER, E.L. A simple technique for quantitation of low levels of DNA damage in individual cells. Exp. Cell Res., v.175, n.1, p.184-191, 1988.

SOBOLEWSKI, C.; CERELLA, C.; DICATO, M.; GHIBELLI, L.; DIEDERICH, M. The role of cyclooxygenase- 2 in cell proliferation and cell death in human malignancies. Int. J. Cell Biol., v.2010, art.215158, p.1-21, 2010.
THIRUGNANASAMPANDAN, R.; JAYAKUMAR, R. Protection of cadmium chloride induced DNA damage by Lamiaceae plants. Asian Pacific J. Trop. Biomed., v.1, n.5, p.391-394, 2011.

TSANG, A.H.; CHUNG, K.K. Oxidative and nitrosative stress in Parkinson's disease. Biochim. Biophys. Acta, v.1792, n.7, p.643-650, 2009.

VIEIRA, R.F.; SIMON, J.E. Chemical characterization of basil (Ocimum spp.) found in the markets and used in traditional medicine in Brazil. Econ. Bot., v.54, n.2, p.207-216, 2000.

WANG, S.; KONOREV, E.A.; KOTAMRAJU, S.; JOSEPH, J.; KALIVENDI, S.; KALYANARAMAN, B. Doxorubicin induces apoptosis in normal and tumor cells via distinctly different mechanisms intermediacy of H2O2-and p53dependent pathways. J. Biol. Chem., v.279, n.24, p.2553525543, 2004.

WILlS, E.D.; THOMAS, J.H.; GILLHAM, B. Wills' biochemical basis of medicine. 2.ed. [S.1.]: Wright, 1989. 590 p.

WOISKY, R.G.; SALATINO, A. Analysis of propolis: Some parameters and procedures for chemical quality control. $J$. Apic. Res., v.37, n.2, p.99-105, 1998.

YUNIS, J.J. High resolution of human chromosomes. Science, v.191, n.4233, p.1268-1270, 1976.

Received for publication on $28^{\text {th }}$ May 2015 Accepted for publication on $18^{\text {th }}$ November 2016 